\title{
Antioxidant activity of Juglans regia L., Juglandaceae pericarp originated from Sumadija region
}

\section{Antioksidativna aktivnost perikarpa Juglans regia L., Juglandaceae poreklom iz Šumadije}

Ksenija Kojicic ${ }^{1}$, Vanja Tadic ${ }^{2}$, Miroslav Sovrlic ${ }^{1}$, Snezana Cupara ${ }^{1}$

1. Department of Pharmacy, Faculty of Medical Sciences, University of Kragujevac, Kragujevac, Serbia

2. Institute of Medical Plants Research "Dr Josif Pancic", Belgrade, Serbia

RECEIVED 27.06.2018.

ACCEPTED 02.09 .2018 .

\section{ABSTRACT}

Objective. The literature provides data on the antioxidant activity of different botanical parts of walnut (Juglans regia L., Juglandaceae) growing in various countries. This research has evaluated the antioxidant activity of pericarp (green husk) of unripe walnut fruit, originated from Sumadija region in Serbia.

Methods. The methanol extract of walnut husk was characterized by the total phenol and tannin content, while antioxidant evaluation was done by DPPH radical scavenging assay.

Results. It has been found that the antioxidant activity of walnut pericarp is within the range $25.32-79.35 \%$ and is concentration dependent. The IC50 is $1.223 \mathrm{mg} / \mathrm{ml}$. The total phenol content was $119.8 \mathrm{mg} \mathrm{GAE} / \mathrm{g}$ and tannin $2.645 \%$.

Conclusion. The investigated parameters of the green walnut pericarp from Sumadija region fit the range of values documented for different parts of walnut species growing in other areas in the world.

Key words: Juglans; nuts; antioxidants; phenols; tannins.

\author{
Ksenija Kojičić ${ }^{1}$, Vanja Tadić ${ }^{2}$, Miroslav Sovrlić ${ }^{1}$, \\ Snežana Cupara ${ }^{1}$ \\ 1. Katedra za farmaciju, Fakultet medicinskih nauka, Univerzitet u Kragujevcu, \\ Kragujevac \\ 2. Institut za proučavanje lekovitog bilja "Dr Josif Pančić", Beograd \\ PRIMLJEN 27.06.2018. \\ PRIHVAĆEN 02.09 .2018 .
}

\section{APSTRAKT}

Cilj. U literaturi su dostupni podaci za antioksidativnu aktivnost razlicitih botanickih delova oraha (Juglans regia L., Juglandaceae) koji raste u razlicitim zemljama. U ovom radu je odredjivana antioksidativna aktivnost perikarpa (zelene ljuske) nezrelog ploda oraha, sa stanistem u Sumadijskom regionu Srbije.

Metode. Metanolni ekstrakt perikarpa oraha je okarakterisan ukupnim sadrzajem fenola i tanina, a antioksidativna aktivnost je ispitana DPPH metodom.

Rezultati. Utvrdjeno je da se antioksidativna aktivnost perikarpa oraha nalazi u opsegu 25.32-79.35\% i zavisi od koncentracije ekstrakta. Vrednost IC50 je $1.223 \mathrm{mg} / \mathrm{ml}$. Ukupni sadržaj fenola iznosio je $119.8 \mathrm{mg} \mathrm{GAE} / \mathrm{g}$, a tanina $2.645 \%$.

Zaključak. Ispitivani parametri perikarpa zelenog oraha iz šumadijskog regiona uklapaju se u opseg vrednosti dokumentovanih za različite delove vrsta oraha koje rastu u drugim oblastima u svetu.

Ključne reči: Juglans; orasi; antioksidansi; fenoli; tanini. 


\section{INTRODUCTION}

Walnut tree (Juglans regia L., Juglandaceae) has been found in a wide area throughout the world - from the Eastern Balkans to the Himalayas and Southwestern China. It grows as a tree, reaching 10-25 $\mathrm{m}$ in height, fruits being commonly used in the human diet. ${ }^{1,2}$ Its natural habitats have been found in Balkan region and Serbia. ${ }^{3}$ All parts of walnut tree have been evaluated for medicinal use. Preparations of walnut roots and leaves have been used in traditional medicine to treat diabetes, rheumatic pain, fever and skin diseases; while flowers have been used in the treatment of malaria and rheumatic pain. ${ }^{4-6}$ Immature walnut fruits have been used in Serbian traditional medicine for preparation of medicinal alcoholic beverage named "orahovača". Hypoglycemic properties of the leaves, bark and fruits have been demonstrated in experimental animal models. Walnut leaves reduced lipid level in streptozotocin-induced diabetic rats. ${ }^{6,8}$ Recent studies have also shown that this plant may possess analgesic and antimicrobial effect. ${ }^{9}$ Due to the high level of phenolic compounds, different parts of walnut tree have been evaluated for antioxidant properties, indicating potential anticancer and anti-inflammatory activity., ${ }^{9,10}$ The pericarp of walnut fruit (green husk) shows antioxidant, antiproliferative and antimicrobial activity. ${ }^{14,16-19}$

Since there has not been data on the antioxidant activity of walnut husk from the species naturally distributed in Sumadija region of Serbia, the aim of this paper was to determine its phenol and tannin content, antioxidant activity and to compare it to the current information available on antioxidant activity of walnut parts from other regions.

\section{MATERIALS AND METHOD}

\section{Plant material}

Fresh, immature walnut fruits were collected in June 2017, in a small town of Lapovo in Sumadija region, Serbia. The plant material was identified by standard botanical keys for plant determination at Institute for Biology and Ecology at the Faculty of Science, University of Kragujevac, Serbia. ${ }^{3,11,12}$

\section{Extraction}

The method used for extraction was maceration. The pericarp (green husk) was peeled off manually, chopped to pieces and mixed thoroughly with $500 \mathrm{ml}$ of methanol. It was allowed to stand at room temperature in a closed glass container, protected from the light during five days, and followed by frequent agitation. The methanol extract was dried using a rotary vacuum evaporator at $40^{\circ} \mathrm{C}$ and stored in a desiccator until the experiment.

\section{Determination of total phenolic content}

The total phenol content was determined by Folin-Ciocalteu method. ${ }^{13}$ The procedure included mixing $100 \mu \mathrm{l}$ of methanol extract with $0.75 \mathrm{ml}$ of Folin-Ciocalteu reagent. The mixture was allowed to stand at $220 \mathrm{C}$. Sodium bicarbonate $(0.75 \mathrm{ml}$ of $60 \mathrm{~g} / \mathrm{l})$ solution was added after $5 \mathrm{~min}$. The mixture was allowed to stand $90 \mathrm{~min}$ at $220 \mathrm{C}$. Absorbance was measured at $725 \mathrm{~nm}$. Gallic acid (0-100 mg/l) was used for calibration of a standard curve. The calibration curve showed the linear regression at $r>0.99$, and the results are expressed as milligrams of gallic acid equivalents per gram of dry extract weight (mg GAE/dw extract).

\section{Evaluation of antioxidant activity}

The total antioxidant activity of the plant extract was assessed by using 2, 2-diphenyl-1-picrylhydrazyl (DPPH) radical scavenging assay. ${ }^{14}$ The method uses the DPPH solution, which was prepared by adding $50 \mathrm{ml}$ of $70 \%$ methanol to $0.002 \mathrm{~g}$ of DPPH. Samples of dry extract were restituted in methanol and filtered. The 4 plant extract samples were prepared in different concentrations $(0.5,1.0,1.5$ and $2 \mathrm{mg} /$ $\mathrm{ml}$ ). The mixture of a sample and DPPH solution was made by addition of $3600 \mu \mathrm{l}$ of DPPH solution to $400 \mu \mathrm{l}$ of extract sample, shaken and allowed to stand at room temperature for 30 minutes in dark place. The reduction of DPPH free radical was measured by the UV-VIS spectrophotometer. The absorbance was noted at $517 \mathrm{~nm}$ against a blank (methanol without plant extract). All tests were carried out in triplicate. Results were presented as the mean \pm SD of three independent measurements. The radical scavenging activity was expressed as percentage of inhibition in all extract samples. This value was calculated using the following formula:

$$
\%=((\mathrm{A} 0-\mathrm{A} 1) / \mathrm{A} 0) \times 100,
$$

where A0 was absorbance of blank at $\mathrm{t}=0 \mathrm{~min}$; A1 was absorbance of the sample at $\mathrm{t}=30 \mathrm{~min}$.

The total antioxidant activity is presented as the sample concentration required to scavenge $50 \%$ of the DPPH radicals (IC50) which was calculated from regression equation for the concentration of extract and percentage inhibition, which was obtained by plotting the percent inhibition against the sample concentration. Lower IC50 values correlate with higher antioxidant activity of the sample.

\section{Determination of tannin content}

The percentage content of tannins in plant extract was examined by the method described in the European Pharmacopoeia Ph. Eur. 7.0.15 Decoctions prepared from the investigated samples were treated with phosphomolybdotungstic reagent in alkaline medium after and without treat- 
ment with hide powder. The absorbance was measured by UV-VIS Spectrophotometer HP 8453, at $\lambda \max 760 \mathrm{~nm}$. The percentage content of tannins was expressed as pyrogallol $(\%, w / w)$ and was calculated as the difference of absorbance of total polyphenols and polyphenols not adsorbed by the hide powder.

The results represent the mean of three determinations.

\section{RESULTS}

Scavenging effect of DPPH radical for concentrations of $0.5 \mathrm{mg} / \mathrm{ml}, 1.0 \mathrm{mg} / \mathrm{ml}, 1.5 \mathrm{mg} / \mathrm{ml}$ and $2.0 \mathrm{mg} / \mathrm{ml}$ of plant extract was $25.32 \%, 41.96 \%, 57.17 \%$ and $79.35 \%$, respectively. We observed that the scavenging effect of DPPH radical was concentration dependent. Higher values of scavenging activity were associated with stronger concentrations of plant extract (Fig. 1).

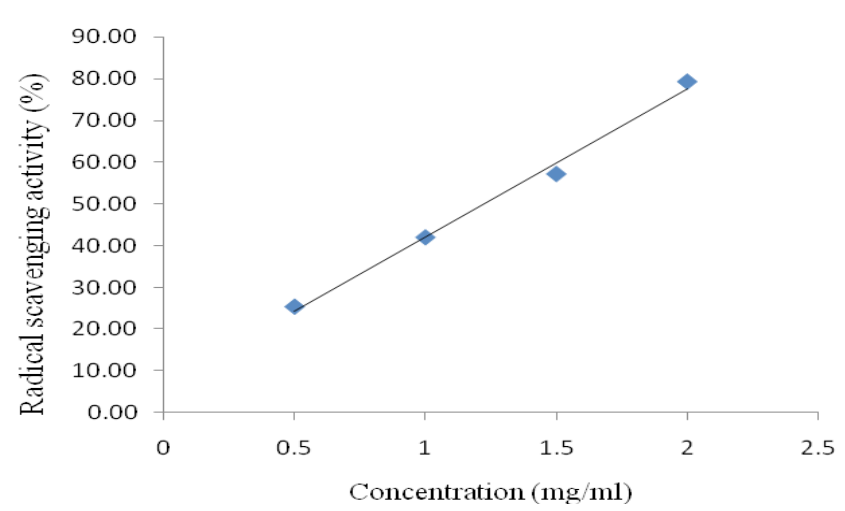

Figure 1. Antioxidant activity of walnut green husk extract.

The concentration of a sample required to scavenge $50 \%$ of the DPPH radical (IC50) was $1.223 \mathrm{mg} / \mathrm{ml}$. The total phenol content in the investigated extract was $119.8 \mathrm{mg}$ GAE/g extract and the tannin content was $2.645 \%$.

\section{DISCUSSION}

The green pericarp of walnut fruit has captured the attention of researchers who attempted to evaluate its antioxidant activity.20 In the absence of data for antioxidant activity of walnut pericarp from Sumadija region, we considered as a prerequisite to study this plant material.

All parts of walnut showed antioxidant activity - research has been carried on leaves, husks, seeds, fruits, shells, pellicles and kernels. ${ }^{10,16-29}$ Several different methods were equally employed for assessing antioxidant activity of different parts of walnut tree - FRAP (Ferric Reduction Antioxidant Power), Hydroxyl Radical Scavenging assay, Nitric oxide scavenging activity, $\beta$-carotene linoleate model system,
TEAC (Trolox Equivalent Antioxidant Capacity), ABTS assay (2,2'-azino-bis(3-ethylbenzothiazoline-6-sulphonic acid), DPPH radical scavenging activity assay and DPPH using EPR (Electron Paramagnetic Resonance). ${ }^{10,16,17,22-29}$ Both IC50 and EC50 appear as suitable for reporting antioxidant activity of different walnut parts. Therefore, in our work, we used IC50 to express the antioxidant activity of walnut pericarp (green husk).

The study conducted in Portugal investigated the antioxidant activity of pericarp extracts obtained by different solvents. Methanolic and petroleum ether extracts of different walnut parts (seed, husk and leaf) were compared. ${ }^{17}$ Methanol seems to be a good solvent for the extraction of compounds contributing to the antioxidant activity since all methanolic extracts showed higher antioxidant activity than petroleum ether extracts. Methanolic extracts were categorized in the following order - the highest antioxidant activity possessed seed extract (EC50 $0.143 \mathrm{mg} / \mathrm{ml}$ ), which was followed by leaf extract (EC50 $0.199 \mathrm{mg} / \mathrm{ml}$ ), and the last was green husk extract (EC50 $0.412 \mathrm{mg} / \mathrm{ml}$ ). Researchers concluded that methanol is more suitable for assessing antioxidant activity then petroleum ether, since the lowest value for antioxidant activity of a methanolic extract (husk) was still higher than the value for petroleum ether husk extract $\left(0.412 \mathrm{mg} / \mathrm{ml}\right.$ and $1.479 \mathrm{mg} / \mathrm{ml}$, respectively). ${ }^{17}$ These findings could be explained by the difference in polarity of solvents. Petroleum ether is non-polar solvent and it has less ability to extract compounds which contribute antioxidant activity than polar solvents.

Researchers from Portugal compared the impact of solvent used for extraction on the antioxidant activity. The plant material was the green walnut husk. They found that highest antioxidant activity showed the extract made by the mixture of water and ethanol, followed by the mixture of water and methanol, pure methanol and pure ethanol (EC50 $0.33 \mathrm{mg}$ / $\mathrm{ml}, 0.34 \mathrm{mg} / \mathrm{ml}, 0.38 \mathrm{mg} / \mathrm{ml}, 0.49 \mathrm{mg} / \mathrm{ml}$, respectively). The lowest antioxidant potential had aqueous green husk extract (EC50 $0.72 \mathrm{mg} / \mathrm{ml}) .{ }^{18}$ Another research group from Portugal found that aqueous extract of walnut fruit husk, from different cultivars collected in Autumn, showed EC50 0.35 $-0.51 \mathrm{mg} / \mathrm{ml}$. They connected the antioxidant activity to the total phenol content since they observed compatibility between stronger antioxidant activity and samples with higher content of phenolic compounds. ${ }^{20}$

Another study of antioxidant activity of walnut methanolic extracts was performed on plant material from Iran, collected in September. It resulted in similar data - the descending order of values for antioxidant activity of different walnut parts was observed for several genotype species that were compared. The highest antioxidant activity had pelli- 
cles, followed by husk, shell and kernels (EC50 $0.15 \mathrm{mg} / \mathrm{ml}$, $0.34 \mathrm{mg} / \mathrm{ml}, 0.41 \mathrm{mg} / \mathrm{ml}$, and $0.77 \mathrm{mg} / \mathrm{ml}$, respectively). ${ }^{23}$

There was a study similar to our work which used unripe, green walnut husks collected in June, but the study employed a mixture of methanol and water for extraction. They obtained results corresponding to the previously reported range for antioxidant activity for different walnut parts (EC50 $0.18 \mathrm{mg} / \mathrm{ml}$ ). ${ }^{28}$ Obtained antioxidant activity was higher than ours, but we assume that this may be due to the changed polarity of the solvent. We have used pure methanol for extraction, while they used the mixture of methanol/ water $(60 \%)$.

We tried to evaluate the antioxidant activity of walnut husk extract originated from the plant growing in Sumadija region and compare it to the available data. Searching the literature data we found that data were presented as IC50 and EC50, since DPPH radical assay employs both values for giving information about the antioxidant activity of different plant parts and those solvents used for walnut extracts were: water, methanol and petroleum ether. We used methanol in our research, because the data indicate that it is the most suitable for the extraction of compounds that contribute to the antioxidant activity. ${ }^{17}$ We found that the antioxidant activity of walnut pericarp extract in our research was EC50 $1.223 \mathrm{mg} / \mathrm{ml}$, which is in accordance with data found for different walnut parts extracted by different solvents. ${ }^{17,20,28}$ The methanol extract of green walnut husk from Sumadija region showed lower antioxidant activity when compared to the methanol extract of walnut husk from Portugal or Iran. We assume that this difference in values for the antioxidant activity of the same walnut part extracted by the same solvent may be due to different habitat conditions and harvesting time which influences the ripening process of pericarp plant tissue. The researchers from Portugal and Iran collected the plant material that had fallen to the ground in the autumn, when fruits shed dry husk to the ground. In our research, however, the plant material was collected in June, while the fruit was unripe and still placed on the branches. Pericarp that was peeled off immature walnut fruit in our research did not fall off the fruit. Instead, it was still connected to the kernel and juicy due to the content of water in active plant tissue.

Antioxidant activity of J. regia pericarp has been attributed to different phenolic compounds. ${ }^{18,20}$ The total content of phenols documented in literature seems to depend on genotype, cultivars, environmental conditions and harvesting season as well as processing of the plant material and solvent used for extraction. ${ }^{18,21}$ Investigating the effect of different polarity solvents on walnut green husk phenol extraction, researchers from Portugal proved that the highest amount of phenols was extracted by $50 \%$ aqueous solution of ethanol ( $84.46 \mathrm{mg} \mathrm{GAE} / \mathrm{g}$ ), followed by $50 \%$ aqueous solution of methanol (81.50 mg GAE/g), pure methanol (65.76 $\mathrm{mg} \mathrm{GAE} / \mathrm{g}$ ) and pure ethanol (51.87 mg GAE/g). The lowest concentration of phenol compounds was found in green husk aqueous extract (40.39 mg GAE/g).18 Phenols found in other extracts of walnut husk are: different cultivars, aqueous extract (32.61 - 74.08 mg GAE/g), petroleum ether extract $(25.06 \mathrm{mg} \mathrm{GAE} / \mathrm{g})$ and methanol/water extract (34.28 mg GAE/ 1g). ${ }^{17,20,28}$ Content of phenol compounds found in our research is higher than the previously reported data (119.8 mg GAE/g), including the data reported for content of phenols in extracts of the walnut husk - $50.18 \mathrm{mg} \mathrm{GAE} / \mathrm{g}$ (collected in September, Portugal) and $26.2 \mathrm{mg} / \mathrm{g}$ GA and $29.5 \mathrm{mg}$ GAE /g (collected in November, Turkey). ${ }^{17,29}$

We present this data as the first results on antioxidant activity of walnut pericarp from Sumadija region. Based on previous studies that connected antioxidant potential of different walnut parts to the concentration of phenols in plant material, we are tend to assume that antioxidant activity of our plant material is also a consequence of the total phenol content. ${ }^{20-29}$ However, we observe a discrepancy between the value of antioxidant activity and the content of phenolic compounds. Antioxidant activity of plant material in our research is lower than reported data, while the content of phenols is higher than the reported data. Though this may be due to the differences in harvesting time, solvents used for extraction or investigated cultivar; we consider that limitations of this work could be overcome by using simultaneously several validated techniques for estimation of antioxidant activity and further determination of all compounds that may influence antioxidant activity of Juglans regia L., Juglandaceae pericarp.

\section{CONCLUSION}

In our study, we determined antioxidant activity, the content of phenols and tannins of walnut green pericarp from Sumadija region. We found that investigated parameters for walnut green pericarp from Sumadija region fit the range of values documented for different parts of walnut species growing in other areas in the world. The promising continuation of this research could include following the fluctuations in the content of the tannins and phenolics in regards to the harvesting time.

\section{CONFLICT OF INTEREST}

Authors declare that there are no conflicts of interest. 


\section{REFERENCES}

1. Delaviz H, Mohammadi J, Ghalamfarsa G, Mohammadi B, Farhadi N. A review study on phytochemistry and pharmacology applications of Juglans regia plant. Pharmacogn Rev 2017; 11: 145-52.

2. Zhao MH, Jiang ZT, Liu T, Li R. Flavonoids in Juglans regia $\mathrm{L}$. leaves and evaluation of in vitro antioxidant activity via intracellular and chemical methods. Sci World J 2014; 2014: 1-6.

3. Josifović M. Flora of SR Serbia. Belgrade. Srpska akademija nauka i umetnosti 1970. (in Serbian).

4. Mohammadi J, Mirzaei A, Azizi A, Rouzbehi A, Delaviz H. The effects of hydroalcoholic extract of Juglans regia leaf on histological changes of Langerhans islet in diabetic rats model. Iran S Med J 2012; 4: 293-301.

5. Mohammadi J, Saadipour K, Delaviz H, Mohammadi B. Anti-diabetic effects of an alcoholic extract of Juglans regia in an animal model. Turk J Med Sci 2011; 41: 685-91.

6. Mohammadi J, Delaviz H, Malekzadeh JM, Roozbehi A. The effect of hydro alcoholic extract of Juglans regia leaves in streptozotocin-nicotinamide induced diabetic rats. Pak J Pharm Sci 2012; 25: 407-11.

7. Asgary S, Parkhideh S, Solhpour A, Madani H, Mahzouni P, Rahimi P. Effect of ethanolic extract of Juglans regia L. on blood sugar in diabetes-induced rats. J Med Food 2008; 11: 533-8.

8. Gholamreza K, Hossein B. Effects of walnut leaf aqueous extract on blood sugar and lipids in male diabetic rats. Saudi Med J 2008; 29: 1350-2.

9. Shah TI, Sharma E, Ahmad G. Juglans regia Linn: a phytopharmacological review. World J Pharm Sci 2014; 2: 364-72.

10. Pereira JA, Oliveira I, Sousa A, et al. Walnut (Juglans regia L.) leaves: phenolic compounds, antibacterial activity and antioxidant potential of different cultivars. Food Chem Toxicol 2007; 45: 2287-95.

11. Javorka S, Csapody V. Iconography Flora of SouthEastern and Central Europe. Budapest: Academiai kido, 1979 (In Latin)

12. Tutin T.G, Burges N.A, Chater A.O, et al. Flora Europaea. 2nd ed. Cambridge. Cambridge University Press, $1993 ; 1: 67$.
13. Velioglu YS, Mazza Gao L, Oomah BD. Antioxidant activity and total phenolics in selected fruits, vegetables, and grain products. J Agric Food Chem 1998; 46: 4113-7.

14. Stanojevic Lj, Stankovic M, Nikolic V, et al. Antioxidant activity and total phenolic and flavonoid contents of Hieracium pilosella L. extracts. Sensors 2009; 9: 5702-14.

15. European Pharmacopoeia Commission. Determinations of tannins in herbal drugs. In: European Pharmacopoeia 7th ed. Council of Europe, Strasbourg Cedex, France, 2014.

16. Wenzel J, Storer Samaniego C, Wang L, et al. Antioxidant potential of Juglans nigra, black walnut, husks extracted using supercritical carbon dioxide with an ethanol modifier. Food Sci Nutr 2016; 5: 223-32.

17. Carvalho M, Ferreira PJ, Mendes VS, et al. Human cancer cell antiproliferative and antioxidant activities of Juglans regia L. Food Chem Toxicol 2010; 48: 441-7.

18. Fernández-Agullóa A, Pereira E, Freirea MS, et al. Influence of solvent on the antioxidant and antimicrobial properties of walnut (Juglans regia L.) green husk extracts. Ind Crop Prod 2013; 42: 126-32.

19. Alshatwi AA, Hasan TN, Shafi G, et al. Validation of the antiproliferative effects of organic extracts from the green husk of Juglans regia L. on pc-3 human prostate cancer cells by assessment of apoptosis-related genes. Evid Based Complement Alternat Med 2012; 2012: 1-8.

20. Oliveira I, Sousa A, Ferreira IC, Bento A, Estevinho L, Pereira JA. Total phenols, antioxidant potential and antimicrobial activity of walnut (Juglans regia L.) green husks. Food Chem Toxicol 2008; 46: 2326-31.

21. Jakopic J, Veberic R, Stampar F. Extraction of phenolic compounds from green walnut fruits in different solvents. Acta Agric Slov 2009; 93: 11-5.

22. Sharma P, Ravikumar G, Kalaiselvi M, Gomathi D, Uma C. In vitro antibacterial and free radical scavenging activity of green hull of Juglans regia. J Pharm Anal 2013; 3: 298-302.

23. Akbari V, Jamei R, Heidari R, Sfahlan AJ. Antiradical activity of different parts of Walnut (Juglans regia L.) fruit as a function of genotype. Food Chem 2012; 135: 2404-10.

24. Ren X, He L, Wang Y, Cheng J. Optimization extraction, preliminary characterization and antioxidant activities of polysaccharides from Semen Juglandis. Molecules 2016; 21: 1-14. 
25. Negi AS, Luqman S, Srivastava S, Krishna V, Gupota N, Darokar MP. Antiproliferative and antioxidant activities of Juglans regia Fruit extract. Pharm Biol 2011; 49: 669-73.

26. Zhang Z, Liao L, Moore J, Wu T, Wang Z. Antioxidant phenolic compounds from walnut kernels. Food Chem 2009; 113: 160-5.

27. Labuckas D, Maestri D, Perello M, Martinez M, Lamarque A. Phenolics from walnut (Juglans regia L.) kernels: antioxidant activity and interactions with proteins. Food Chem 2008; 107(2): 607-12.

28. Rahimipanah M, Hamedi M, Mirzapour M. Antioxidant activity and phenolic contents of Persian walnut (Juglans regia L.) green husk extract. Afr J Food Sci Technol 2010; 1: 105- 11 .

29. Akin M, Arabaci G, Saki N. Total phenols, antioxidant potential and tyrosinase inhibitory activity of walnut (Juglans regia L.) leaf, husk and seed. Asian J Chem 2013; 25: 9337-40. 